\title{
Foreword 1996
}

A friend of mine tells a story about some Israeli students who were called up in the 1973 Yom Kippur War. As soon as they were notified, they went back to their rooms at the University, and each packed his gear, a rifle, and a book of Yehuda Amichai's poems. It is a little hard to envision this scene: these days we don't think of soldiers as resorting to poetry under fire, and Amichai's poetry is not standard government issue. It isn't patriotic in the ordinary sense of the word, it doesn't cry death to the enemy, and it offers no simple consolation for killing and dying.

Still, I know what these young soldiers were after, because I have often found myself turning to Amichai's poetry as a kind of restorative. Pungent, ironic, tender, playful and despairing by turns, it draws me by the energy of its language, the exuberant inventiveness and startling leaps that freshen the world, making it seem a place where anything is possible. And by the humor, too-a briny Jewish humor that can set the teeth on edge. And I am attracted by a certain astringent quality of mind, a skeptical intelligence that is impatient with camouflage and pathos and self-deceit, that insists on questioning even what it loves.

Love is at the center of Amichai's world, but he is quick to grant that his mistress's eyes are nothing like the sun, that sex is at once an enticing scent and a sticky business. And Jerusalem, the beloved city, he contemplates with a mixture of love and exasperation. No one has written more intimately about this landscape - the dust and stones and the ghosts of barbed-wire fences; the Old City with its Wailing Wall and mosques and churches, its Solomon and Herod and Suleiman the Magnificent, all under a cloud of prophecy; the foreign consulates and the housing projects; the Jews and the Arabs; the zealous black-coated Hasidim and the tourists; the brooding presence of the dead.

Amichai's way of seeing this place - and most things he writes aboutfrom both the inside and outside, balancing tenderness against irony, reflects his experience of two very different worlds. Born in Würzberg, Germany, in 1924, he grew up in an Orthodox Jewish home with its strict religious observance and its protective God, as inescapable as family. His father was a shopkeeper, his grandfather a farmer, and his memories of childhood (the political situation notwithstanding) idyllic. In 1936 he came to Palestine with 
his parents, and his adult life has been lived in the midst of the convulsive struggle of Israel to become a state, and then to survive and define itself. Amichai made his living as a teacher while studying war-as a soldier with the British army in World War II, with the Palmach in the Israeli War of Independence in 1948, and with the Israeli army in 1956 and 1973. He was formed half by the ethics of his father and half by the cruelties of war.

Throughout his career, he has written about memory and the burdens of memory; about the lingering sweetness and simplicity of his parents' lives set against the perplexities of his own; about war as loss and love as a hedge against loss. The most troubling loss is that of his childhood, left behind in the normal course of life and then destroyed by war. "My childhood of blessèd memory," he calls it, borrowing an expression commonly used when speaking of the dead.

Amichai holds on tightly to whatever he has lost. "What I will never see again I must love forever" is his first article of faith. That is why there are so many elegies of love here. And that is why the God in these poems, who at times seems no more than a figure of speech, deeply embedded in the language, makes his presence strongly felt even in his absence. Amichai's quarrel with God is what stamps this poetry as so unmistakably Jewish. That quarrel carries on the venerable tradition of Abraham, Jeremiah, and Jobthough the object of his irony is the Bible as well, not least the visionary fervor of the prophets. As he writes in "When I Banged My Head on the Door," a poem that may be taken as his ars poetica:

When I banged my head on the door, I screamed, "My head, my head," and I screamed, "Door, door," and I didn't scream "Mama" and I didn't scream "God."

And I didn't prophesy a world at the End of Days

where there will be no more heads and doors.

What Amichai loves best is the ordinary human being with his pain and his joy, a museum in his heart and shopping baskets at his side. In "Tourists" it's not the Roman arch he wants us to care about but the man sitting nearby with the fruit and vegetables he has just bought for his family.

Amichai began to write in 1948; his first collection of poetry appeared in 1955. Since then he has published eleven volumes of poetry, many of them best sellers, as well as novels, short stories, and plays. His poems enjoy an enormous popularity in Israel. They are recited at weddings and funerals, taught in the schools, and set to music. And for a poet so rooted in his own place, his work is remarkably well known outside of Israel, having been translated into some thirty-three languages, including Chinese, Japanese, and Albanian.

The poems in this volume, chosen from Amichai's best work over a productive career of nearly half a century, should give some notion of his stylis- 
tic range: long poems and short, rhymed and unrhymed, in formal meters and in free verse; poem cycles; prose poems and poems hovering at the borders of prose; poems of an overflowing abundance and poems of a tightly coiled concision. All the translations are our own: Stephen Mitchell translated the poems written before 1969, and I translated the later ones. Many of these have not previously appeared in English.

The poems lend themselves to translation because they speak clearly and directly, and because Amichai's striking metaphors carry the burden of his meaning. But his language is far more dense and inventive than this may suggest. Reading these poems in Hebrew, one encounters allusions to biblical and liturgical texts on every page. The Israeli reader, even one who has not had Amichai's formal religious education, will have studied the Bible from grade school through college, and is also likely to recognize the kind of liturgical texts that Amichai refers to, such as the Mourner's Kaddish or the Yom Kippur service. Because this is obviously not true of most readers of English, we have often borrowed from or imitated the King James Bible as a way of pointing up allusions that might otherwise have gone unnoticed. On the other hand, modern Hebrew, revived as a spoken language only a hundred years ago, is much closer to the Hebrew of the Old Testament than our own language is to seventeenth-century English, and Amichai's allusions never have a "literary" air. So when we felt that the archaisms of the King James version intruded awkwardly on the naturalness and ease of Amichai's diction, we found other equivalents. And when an allusion would have required too much explanation, we sometimes chose to disregard it.

To write poetry in Hebrew is to be confronted with the meaning of Jewish experience, from biblical times to the present day, in all its strangeness and complexity. Amichai's provocative allusions-ranging from the witty and mischievous ("The man under his fig tree telephoned the man under his vine") to the subversive and iconoclastic ("The army jet makes peace in the heavens") - are one way of wrestling with the angel of history. The necessity of confronting the past is imposed by the language itself; it is Amichai's achievement to have found in that wrestling his distinctive identity as a poet:

to speak now in this weary language,

a language that was torn from its sleep in the Bible: dazzled,

it wobbles from mouth to mouth. In a language that once described miracles and God, to say car, bomb, God.

To use the words "bomb" and "God" in the same breath in Hebrew is to change the landscape of the language.

Amichai never lets us forget the human cost of war: the bereaved father who "has grown very thin, has lost / the weight of his son," the everwidening circle of mourners after a bomb attack, including the orphans whose outcry 
... reaches up to the throne of God and

beyond, making

a circle with no end and no God.

And he has consistently questioned the heroic ideal of Israel's early years, setting in its place the dream of an ordinary life.

Since he is Israel's most beloved poet, and since Israeli society is unusually receptive to poetry, one may say that he has in some measure helped to prepare the way for peace. This was publicly acknowledged when Yitzhak Rabin and Shimon Peres received the Nobel Peace Prize together with Yasir Arafat in 1994. Invited to participate in the awards ceremony in Oslo, Amichai read "Wildpeace," written over twenty years earlier, when the notion of peace seemed dismally remote. In this poem he brushes aside the grand rhetoric of the prophets - the vision of the wolf and the lamb, or what he sardonically calls "the big noise of beating swords into ploughshares" - and speaks of peace as a simple necessity:

Let it come

like wildflowers, suddenly, because the field

must have it: wildpeace.

In his acceptance speech, Rabin read one of Amichai's best-known poems, "God Has Pity on Kindergarten Children," which begins:

God has pity on kindergarten children.

He has less pity on school children.

And on grownups he has no pity at all, he leaves them alone, and sometimes they must crawl on all fours

in the burning sand

to reach the first-aid station

covered with blood.

Amichai's lines seem chillingly apt in the light of Rabin's assassination at a peace rally less than a year later.

Just as the young soldiers carried Amichai's words with them into battle, the old soldier Rabin brought them into the dangerous arena of peacemaking, and for the same reason. There they go on civilizing our hearts, reminding us - for we need to be reminded -

that the fist, too,

was once the palm of an open hand, and fingers.

Chana Bloch 
For Hana 
This page intentionally left blank 